\title{
Review of Physical Condition of Football School Players Aged 15 in Padang Panjang
}

\author{
Rosmaneli* \\ Sport Education Program \\ Faculty of Sport Science \\ Padang State University \\ Padang, Indonesia \\ rosmaneli@fik.unp.ac.id
}

\begin{abstract}
This study aimed to find out how the physical condition of the football school players. This type of research is descriptive. The population in this study was 45 GMG Football School players. The sample was taken by using a purposive sampling technique so that a sample of 20 people was set. The data was taken by using the Yo-Yo Intermittent Recovery Test, The Arrowhead Agility Test, Fleksiometer, and sprint 50 meters. The data were analyzed using frequency calculation techniques. The results show that : (1) the average speed of the GMG football school player was 7.9 - 6.9 seconds, and it was in the average category. (2) The average agility of GMG football school players was 18 seconds, and it was in terrible category the average agility of GMG U-15 SSB in Padang Panjang city is more than 18 seconds with a deficient category. (3) The average endurance of the GMG football school player was less than 1800 meters, and it was in a deficient category. (4) The average of the flexibility of the GMG football school player was $1-5 \mathrm{~cm}$, and it was in the very bad category.
\end{abstract}

Keywords - physical conditions, football players

\section{INTRODUCTION}

Sport is an essential activity as a part of human life. Therefore, sports are increasingly favored by many people, as athletes or hobbies. Exercise can improve health, strength, maintain sportsmanship, and social values in society. It is is in line with what is affirmed by [1] "National sports aims to maintain and improve prosperity and fitness, achievement, human quality, instill mental values and noble character, sportsmanship, discipline, strengthen national defense, and elevate the nation's dignity.“

Based on the Law above, it can be said that development and establishment of sports is very important and aims to improve physical fitness and achievement. Nowadays, one of the most favorite sports is soccer. Almost all people like this sport. By its popularity, many football schools (basic and advanced) come up. Football schools are expected to create quality player. Besides football school, there are other factors such as such as means of developing achievement, and fostering good and continuous athletes, physical condition, technique, tactics, and mentality to support the quality of player.

Ehlenz/ Grosser/ Zimmerman in [2] stated four important factors to support the quality of player,

"As elements of sport achievement, the performance displayed or exhibited by an athlete, individually or in a team, is a combination of the physical, technical, tactic, and mental conditions of the athlete. The four elements are united in a single frame known as sports achievements".

Of the four determinants of achievement, physical condition is a factor that greatly influences one's achievement. Without good physical condition, technique, tactics and mentality cannot work perfectly. In Indonesia Dictionary, it is explained that physical condition is the condition or state of body of a person who is expected to achieve achievement.

By having a good physical condition, someone will be able to do sports activities properly. [3] states, "physical condition is the most dominant basic preparation to be able to do a maximum physical activity".

In soccer there are several physical conditions such as: speed, agility, endurance, and flexibility.

[4] says, "speed is the ability to make similar movements in a row or cover a distance in the shortest possible time". Rusli luitan, et al (2010 : 36) explains, "agility is the ability of a person to change direction quickly and precisely without losing balance". [2] says, "endurance is one's ability to overcome fatigue due to physical work for a long time". [5] propose, "flexibility is the ability of a person to be able to make joints as wide as possible." By adjusting some of the capabilities of these physical conditions, of course a soccer player will be able to optimize the elements of technique and tactics well. In other words, physical condition is the basis for having optimal technical and tactic abilities.

Based on the author's observations during training, testing and competition at the football school level, it was obtained several phenomena such as, in the first round, the players can master the game and teamwork well and can adjust the of the game so they can create opportunities to kick goals. However, in the second half, the players started making mistakes, such as inaccurate shots, decreased stamina, lack of concentration in playing, poor teamwork, and weak in fighting opponents' attacks.

\section{RESEARCH METHODOLOGY}

This research belongs to descriptive research. This research was conducted in the Padang Panjang Gantiang Field in April-May 2019. The population was the soccer 
player of Generasi Muda Gantiang (GMG) football school. The sample was soccer player of Generasi Muda Gantiang (GMG) football school who are in the age of 15 years old. The data used were primary and secondary data. The instruments used to measure agility were The Arrowhead agility test; flexibility used the Flexsiometer test; speed used the 50 meter sprint test; and endurance used the Yo-Yo intermittent test. The data analysis technique used was the calculation of frequency and percentage.

\section{RESULT AND DISCUSSION}

\section{Speed (50 meters running)}

Based on the research, it was found that the best score of speed is 8,4 ; the lowest score of speed was 7,1 ; the Average (mean) was 14.6; and standard deviation was 0.37 . The details can be seen in the table below.

Table 1 : Speed Frequency Distribution

\begin{tabular}{|c|c|c|c|}
\hline \multirow{2}{*}{ Norm } & \multicolumn{2}{|c|}{ Frequency } & \multirow{2}{*}{ Category } \\
\cline { 2 - 3 } & Absolute & Relative & \\
\hline$<4,6$ & 0 & $0 \%$ & Excellent \\
\hline $5,7-4,7$ & 0 & $0 \%$ & Very Good \\
\hline $6,8-5,8$ & 0 & $0 \%$ & Good \\
\hline $7,9-6,9$ & 16 & $80 \%$ & Average \\
\hline$>8,0$ & 4 & $20 \%$ & Bad \\
\hline Total & 20 & $100 \%$ & \\
\hline
\end{tabular}

\section{Agility (The Arrowhead Agility Test)}

Based on the research, it was found that the best time was 18,51; the longest was 22,30 ; the mean was 38,94 ; and standard deviation was 1,24 . The details can be seen in the table below.

Table 2 : Agility Frequency Distribution

\begin{tabular}{|c|c|c|c|}
\hline \multirow{2}{*}{ Norm } & \multicolumn{2}{|c|}{ Frequency } & \multirow{2}{*}{ Category } \\
\cline { 2 - 4 } & Absolute & Relative & \\
\hline$<14,0$ & 0 & $0 \%$ & Excellent \\
\hline $14,0-15,0$ & 0 & $0 \%$ & $\begin{array}{c}\text { Very } \\
\text { Good }\end{array}$ \\
\hline $15,0-16,0$ & 0 & $0 \%$ & Good \\
\hline $16,0-17,0$ & 0 & $0 \%$ & Average \\
\hline $17,0-18,0$ & 0 & $0 \%$ & Bad \\
\hline$>18,0$ & 20 & $100 \%$ & Very Bad \\
\hline Total & 20 & $100 \%$ & \\
\hline
\end{tabular}

\section{Endurance (Yo-Yo Intermittent Recovery Test)}

Based on the research, it was found that the highest score was 1800; the lowest score was 640; the mean score was 2057; and standard deviation was 383,00. The details can be seen in the table below.
Table 3 : Endurance Frequency Distribution

\begin{tabular}{|c|c|c|c|}
\hline \multirow{2}{*}{ Norm } & \multicolumn{2}{|c|}{ Frequency } & \multirow{2}{*}{ Category } \\
\cline { 2 - 3 } & Absolute & Relative & \\
\hline$>3000$ & 0 & $0 \%$ & Excellent \\
\hline $2760-3000$ & 0 & $0 \%$ & Very Good \\
\hline $2600-2720$ & 0 & $0 \%$ & Good \\
\hline $2200-2560$ & 0 & $0 \%$ & Average \\
\hline $1800-2160$ & 1 & $5 \%$ & Bad \\
\hline$<1800$ & 19 & $95 \%$ & Very Bad \\
\hline Total & 20 & $100 \%$ & \\
\hline
\end{tabular}

\section{Flexibility (Flexiometer Test)}

Based on the research, it was found that the

highest score was 14 ; the lowest score was 1 ; mean score was 7,05; and standard deviation 3,15 . The details can be seen in table below

Table 4 : Flexibility Frequency Distribution

\begin{tabular}{|c|c|c|l|}
\hline \multirow{2}{*}{ Norm } & \multicolumn{2}{|c|}{ Frequency } & \multirow{2}{*}{ Category } \\
\cline { 2 - 3 } & Absolute & Relative & \\
\hline$>24 \mathrm{~cm}$ & 0 & $0 \%$ & Excellent \\
\hline $18-23 \mathrm{~cm}$ & 0 & $0 \%$ & Very Good \\
\hline $12-17 \mathrm{~cm}$ & 1 & $5 \%$ & Good \\
\hline $6-11 \mathrm{~cm}$ & 3 & $15 \%$ & Average \\
\hline $1-5 \mathrm{~cm}$ & 16 & $80 \%$ & Bad \\
\hline Total & 20 & $100 \%$ & \\
\hline
\end{tabular}

\section{DISCUSSION}

1.Speed

Based on speed test result, the highest score was 8,4 and the lowest score was 7,1. Based on frequency distribution table and histogram, there was nothing for excellent, very good, and good category; there was 16 players (80\%) for average category; and there was $20 \%$ for bad category. It can be concluded that the speed of player was in average category.

Based on the result, it can be said that the player of GMG football school age 15 need to improve the quality of speed. The speed training program must be arranged in the form of an established training program.

\section{Agility}

Based on agility test result, the fastest was 18,51 , and the slowest was 22,30. In table 2 above, it can be seen that there is nothing in excellent, very good, good and average category. However, there were 20 people $(100 \%)$ in very bad category. Thus, it can be concluded that the agility of the player was very bad. It is because they were lazy to practice; they only did the practice in field; they were less discipline; they were lack of presence. Besides, the training program designed by the trainer was not working optimally.

\section{Endurance}

Based on endurance test result, it was found that the highest score was 1800, and the lowest score was 640 . From table 3 above, it can be said that there was nothing in excellent, very good, good, and average category. 
There was 1 person $(5 \%)$ on category bad and there were 19 people in very bad (95\%) category. It can be conclude that the endurance of player GMG football school was very bad.

The low endurance is because the player were lazy in physical condition training, especially in endurance training; attendance in training was rather lacking, so the program designed by the trainer was not work properly. They only had twice practice in week without having repetion at home. Also, less hour sleep affected their physical condition, especially endurance.

\section{Flexibility}

Based on flexibility test result, it was found that there was nothing in very good and good category. There was 1 person $(5 \%)$ in average category; there were 3 people $(15 \%)$ in bad category, and there were 16 people $(80 \%)$ in very bad category. Thus, it can be concluded that the flexibility of GMG football school player was in very bad category.

\section{CONCLUSION}

Based on the findings, it can be concluded that :

1. The average of speed of GMG football school player was $7.9-6.9$ seconds, and it was in average category.

2. The average of agility of GMG football school player was 18 second, and it was in very bad category.

3. The average of endurance of GMG football school player was less than 1800 meters, and it was in very low category.

4. The average of flexibility of GMG football school player was $1-5 \mathrm{~cm}$, and it was in very bad category.

\section{REFERENCES}

[1] UU.RI.NO.3, 2005. "Sistem Keolahragaan Nasional". Bandung : Citra Umbara.2005.PP.12-25.

[2] Syafruddin. "Ilmu Kepelatihan Olahraga". Padang : FIK UNP Padang. 2012.PP.10-45.

[3] Arsil. "Pembinaan Kondisi Fisik". Padang : FIK UNP. 2015.PP.5565.

[4] Bafirman. "Buku Ajar Pembentukan Kondisi Fisik". Padang : FIK UNP. 2016.PP.20-44.

[5] L. Rusli dkk. "Manusia dan Olahraga". Bandung : ITB dan FPQK/IKIP. 2012.PP.30-44. 